\title{
MENINGKATKAN TATA KELOLA DESA DAN PERILAKU HIDUP SEHAT MENUJU ERA NEW NORMAL
}

\author{
Umi Nandiroh*, Akbar, Erlin Afrianti, Nurul Yuniarti, Elmia Ikhmawati, Rovita Tri \\ Rezeki, Nuranisa, Sa'ati, Jumratih, Santi Martia Dekayanti \\ Fakultas Ekonomi dan Bisnis, Universitas Islam Malang \\ *Korespondensi email: uminandiroh@unisma.ac.id
}

\begin{abstract}
ABSTRAK
Corona Virus adalah penyakit yang menyebabkan infeksi saluran nafas pada manusia mulai dari batuk pilek hingga yang lebih serius seperti Middle East Respiratory Syndrome (MERS) dan Severe Acute Respiratory Syndrome (SARS) (Guan, dkk 2020). Coronavirus jenis baru yang ditemukan menyebabkan penyakit COVID-19 (WHO, 2020). Dengan adanya upaya pemerintah dalam menangulangi penyebaran covid-19 ini di wajib kepada seluruh masyarakat untuk tetap menerapkan perilaku hidup sehat dan mematuhi protokol kesehatan yang telah ditetapkan oleh pemerintah seperti sosial dastancing dan tetap memakai masker dan hand sanitizer saat ada keperluan mendesak. Dampak yang dapat dirasakan dari wabah ini yaitu krisis ekonomi bagi masyarakat, jadi dapat diberikan solusi seperti adanya sosialisasi ketahan ekonomi di masa pandemi.
\end{abstract}

Kata Kunci: pencegahan covid-19; perilaku hidup sehat; tata kelola desa.

\section{PENDAHULUAN}

Corona virus adalah suatu kelompok virus yang dapat menyebabkan penyakit saluran nafas pada manusia mulai dari batuk pilek hingga yang lebih serius seperti Middle East Respiratory Syndrome (MERS) dan Severe Acute Respiratory Syndrome (SARS) (Guan, dkk 2020). Coronavirus jenis baru yang ditemukan menyebabkan penyakit COVID-19 (WHO, 2020). Hingga kini laju persebaran Corona virus Disease2019 (COVID-19) meningkat semakin cepat cepat melalui tetesan air liur atau keluar dari hidung ketika orang yang terinfeksi batuk atau bersin. Wabah virus covid- 19 telah menyebar ke berbagai negara di dunia dengan waktu yang sangat singkat, salah satunya adalah Indonesia. Saat ini, masalah yang di timbulkan dari virus Covid- 19 tidak hanya persoalan kesehatan, namun juga menyangkut perekonomian. Virus Covid-19 ini telah mengakibatkan krisis ekonomi yang sangat dalam dan berdampak bagi kehidupan masyarakat di Indonesia.

Upaya pemerintah dalam menanggulangi penyebaran COVID-19 yang sangat cepat ini sudah mencakup banyak aspek kehidupan. Di bidang pendidikan, pemerintah menerapkan pelaksanaan program belajar di rumah (Kemendikbud, 2020). Hal ini bisa melalui berbagai media berbasis internet maupun melalui media yang tidak berbasis internet (Darmalaksana, dkk 2020). Di bidang sosial masyarakat, pemerintah dengan gencar mencanangkan konsep mitigasi komunitas, berupa pengurangan frekuensi pertemuan besar, pembatasan jarak antar orang di fasilitas umum, hingga penerapan konsep aktivitas yang lebih baik dilaksanakan di rumah. Di bidang kesehatan, pemerintah telah dengan gencarnya mengedukasi masyarakat terkait pentingnya hidup bersih dan sehat, perlunya mengenakan 
masker saat di luar rumah, pelaksanaan karantina mandiri untuk orang-orang yang memiliki risiko tinggi, serta berbagai pedoman yang bertujuan untuk mencegah penularan COVID-19 (Telaumbanua, 2020). Di bidang agama pun, pemerintah melalui Majelis Ulama Indonesia (MUI) telah memberikan fatwa terkait dengan pelaksanaan ibadah di masa wabah pandemi COVID19 (MUI, 2020). Hingga pada tingkat desa, pemerintah telah mengeluarkan protokol terkait Relawan Desa Lawan COVID-19 (Kemendesa, 2020).

Namun, meskipun pemerintah telah melakukan berbagai upaya dalam menanggulangi penyebaran COVID-19, penambahan kasus positif COVID-19 di Indonesia semakin bertambah. Hal ini disebabkan karena kurangnya pengetahuan terhadap pandemi yang berimplikasi terhadap minimnya kesadaran masyarakat sehingga penanganan (pencegahan bagi yang tidak terinfeksi dan atau pengobatan terhadap yang terkena wabah) kurang terintegrasi-interkoneksi dalam sistem pemerintahan di negara kita. Dari pusat sampai bagian paling bawah, yaitu desa (kampung). Hal ini sangat berbahaya karena penyebaran COVID-19 sangat rentan tertular melalui mata, hidung, dan mulut (WHO, 2020).

Sebagai salah satu civitas akademika yang memiliki tugas Tri Dharma Perguruan Tinggi terpanggil untuk turut berkontribusi bersama dalam menghadapi COVID-19. Dengan melihat situasi di Desa Sepakat, Kecamatan Plampang, saya melakukan kegiatan pengabdian kepada masyarakat dalam bentuk kegiatan Kuliah Kerja Nyata (KKN) UNISMA edisi COVID19. Kegiatan KKN (Kuliah Kerja Nyata) dengan melakukan edukasi pemahaman dan berkontribusi dalam pelaksanaan penanggulangan COVID-19 melalui protokol kesehatan yang ada.

Berdasarkan latar belakang masalah diatas, maka pengabdi tertarik untuk melakukan KKN dengan melakukan edukasi di masyarakat Desa Sepakat, Kecamatan Plampang dalam melakukan penanggulangan COVID-19 melalui program edukasi pencegahan penyebaran dan penularan COVID-19. Dalam mencegah penularan dan penyebaran COVID-19 ini, saya mengedukasi masyarakat melalui pemberian pemahaman tentang COVID-19, pentingnya penggunaan masker saat berpergian, pentingnya memakai hand sanitizer saat berada di luar rumah dan pentingnya mencuci tangan yang benar. Maka dari itu, artikel ini membahas mengenai kegiatan KKN di Desa Sepakat, Kecamatan Plampang melalui edukasi kepada masyarakat serta pemahaman mengenai pentingnya mengikuti aturan protokol kesehatan dalam penanggulangan COVID-19.

\section{METODE}

Kegiatan yang dilakukan dengan metode Edukasi COVID-19 kepada Masyarakat di Desa Sepakat, Kecamatann Plampang. Pada program KKN ini dilakukan edukasi tata kelolah desa dan prilaku hidup sehat di masa pandemi COVID-19 yaitu pembagian masker dan hand sanitizer, penempelan poster edukasi COVID-19 di Masjid, Pasar dan tempat yang memicu keramaian, dan melakukan sosialisasi BUMDes dengan tema "REVITALISASI BUMDes MENUJU KETAHANAN EKONOMI DESA" melalui aplikasi Zoom.

\section{HASIL DAN PEMBAHASAN}

Program KKN dilakukan dengan menerapkan protokol pemerintah yaitu work from home dan social distancing. Adapun program yang akan dilakukan yaitu Edukasi Masyarakat terhadap COVID-19.

\section{Identifikasi Masalah}

Dari latar belakang masalah yang ada, program KKN yang dilakukan berdasarkan kalsifikasi yang terdapat pada Tabel 1. 
Tabel 1. Program KKN

\begin{tabular}{|c|c|c|c|}
\hline No & Masalah & Alternatif Pemecahan & Bentuk Kegiatan \\
\hline 1 & $\begin{array}{l}\text { Masyarakat belum mengetahui } \\
\text { pentingnya penggunaan masker } \\
\text { di masa covid-19 }\end{array}$ & $\begin{array}{l}\text { Memberikan edukasi terhadap } \\
\text { pentingnya pemakaian masker. }\end{array}$ & $\begin{array}{l}\text { Memberikan masker dan } \\
\text { membagikan hand sanitizer } \\
\text { kepada masyarakat yang } \\
\text { terdampak covid-19 }\end{array}$ \\
\hline 2 & $\begin{array}{l}\text { Masyarakat belum memahami } \\
\text { cara cuci tangan yang benar } \\
\text { sesuai anjuran WHO. }\end{array}$ & $\begin{array}{l}\text { Memberikan edukasi tentang } \\
\text { tata cara cuci tangan yang baik } \\
\text { dan benar. }\end{array}$ & $\begin{array}{l}\text { Melakukan demonstrasi cara cuci } \\
\text { tangan yang baik dan benar. }\end{array}$ \\
\hline 3 & $\begin{array}{l}\text { Masyarakat belum menemukan } \\
\text { inovasi pemekaran potensi } \\
\text { desa. }\end{array}$ & $\begin{array}{l}\text { Melakukan inovasi baru salah } \\
\text { satu potensi desa yaitu buah } \\
\text { sawo. }\end{array}$ & $\begin{array}{l}\text { Pembuatan puding sawo dan dodol } \\
\text { sawo yang dipamerkan dalam lomba } \\
\text { desa. }\end{array}$ \\
\hline 4 & $\begin{array}{l}\text { Masyarakat belum mampu } \\
\text { mengelolah lahan perkarangan } \\
\text { sekitar rumah }\end{array}$ & $\begin{array}{l}\text { Melakukan edukasi pengolahan } \\
\text { lahan kosong. }\end{array}$ & $\begin{array}{l}\text { Membagiakan bibit sayur dan } \\
\text { Mengedukasi cara pengolahan } \\
\text { lahan kosong dengan menanam } \\
\text { tanaman hortikultura dalam poly } \\
\text { bag }\end{array}$ \\
\hline
\end{tabular}

\section{Pelaksanaan Kegiatan}

Pada KKN edisi COVID-19 ini edukasi berfokus pada masyarakat di Desa Sepakat, Kecamatan Plampang. Masyarakat diberikan penjelasan mengenai pemahaman tentang COVID-19 berdasarkan sumber terpercaya, sehingga masyarakat mendapatkan informasi yang bisa diterapkan pada keseharian. Berikut kegiatan-kegiatan dari program kerja KKN edisi COVID-19 di Desa Sepakat, Kecamatan Plampang.

a. Kegiatan Minggu Pertama

> Pemasangan poster protokol kesehatan di titik-titik tertentu yang memicu keramaian seperti Pasar dan Masjid/musholah.

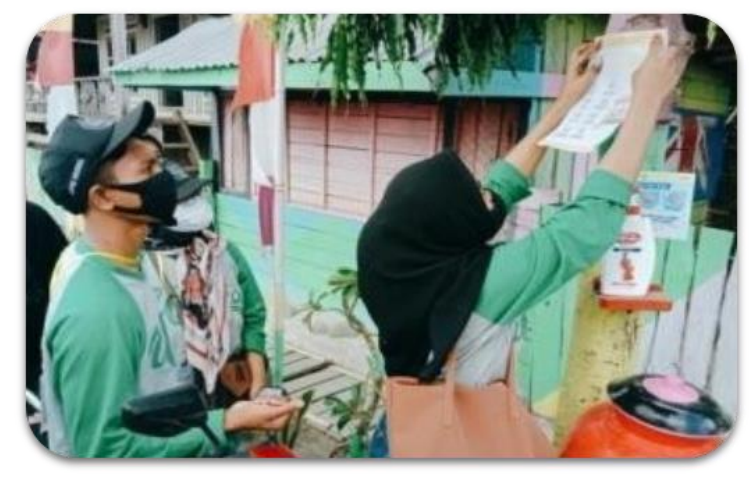

Gambar 1. Pemasangan poster ole mahasiswa KKN

Pembagian bibit sayur dan edukasi penanaman sayur dengan media pily

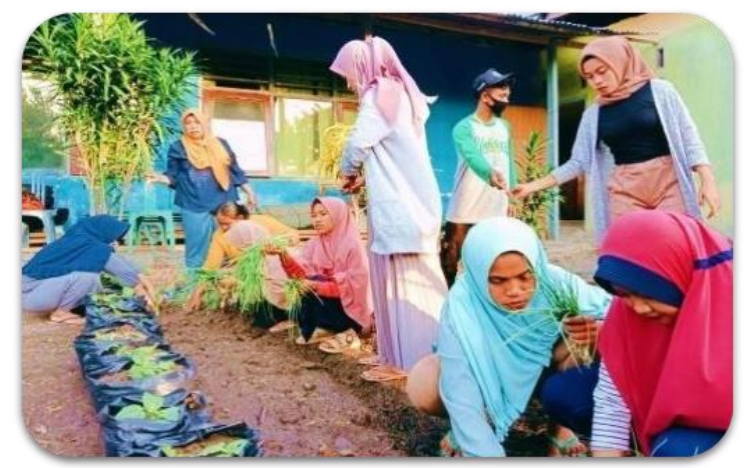

Gambar 2. Penanaman bibit sayuran 
b. Kegiatan Minggu Kedua

$>$ kegiatan pada minggu kedua, melakukan demonstrasi cara cuci tangan dengan baik dan benar secara bergantian dari rumah ke rumah

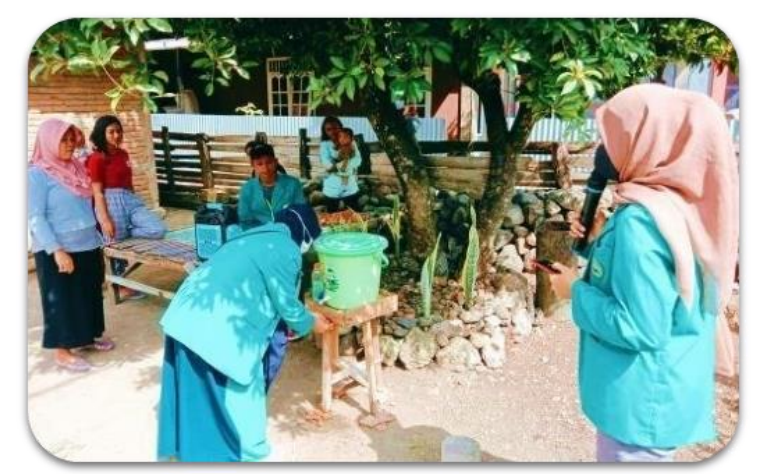

Gambar 3. Demonstrasi cara cuci tangan dengan baik dan benar

Pembuatan puding \& dodol dari olahan sawo khas Desa Sepakat

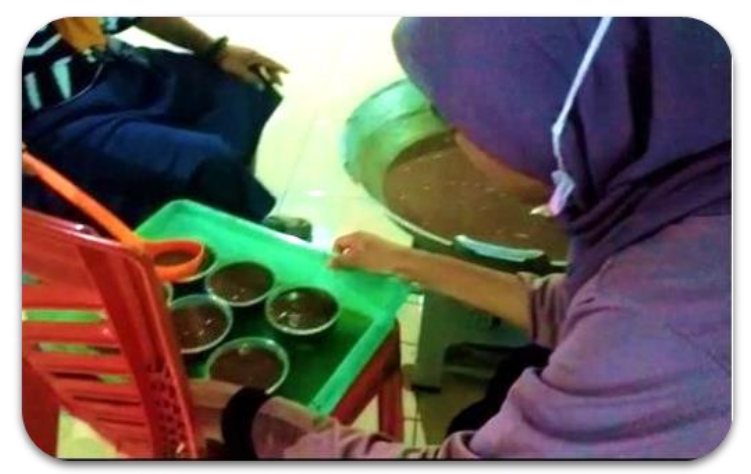

Gambar 4. Pembuatan puding \& dodol

c. Kegiatan Minggu Ketiga

kegiatan pada minggu ketiga, melakukan pembagian masker dan hand sanitizer.

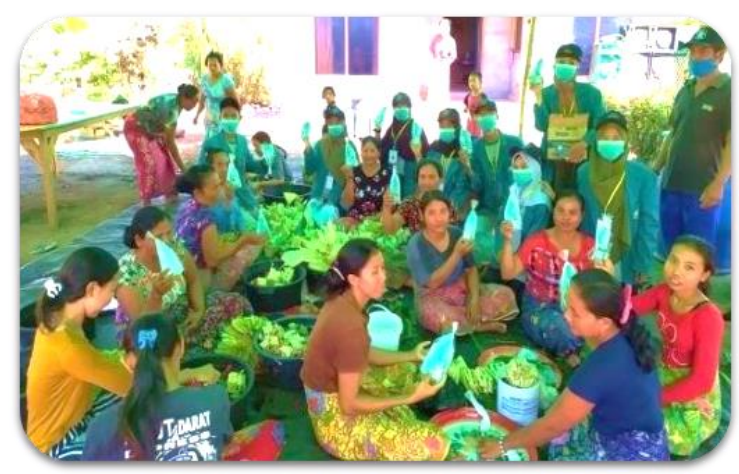

Gambar 5. Pembagian masker dan hand sanitizer

d. Kegiatan Minggu Keempat

$>$ Kegiatan pada minggu keempat, melakukan sosialisasi kepada anggota BUMDes dengan pemaparan materi tentang revitakisasi BUMDes dan ketahanan ekonomi desa dengan via zoom. Sosialisasi ini bertujuan untuk mengembangkan BUMDes dan inovasi BUMDes kedepannya. 


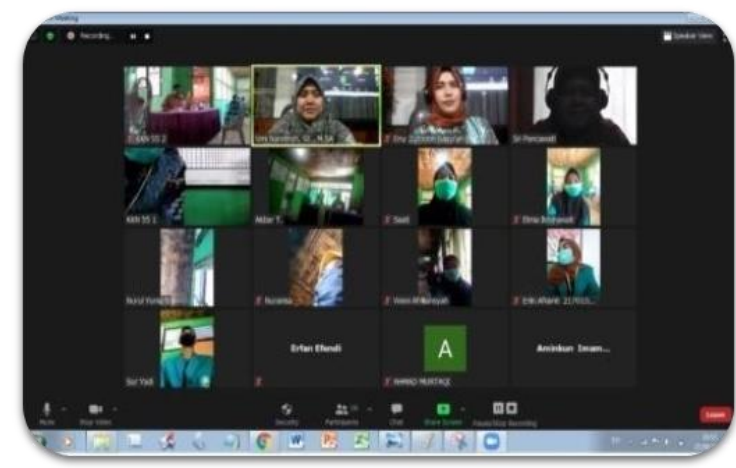

Gambar 6. Sosialisasi BUMDes secara daring

Merayakan Hut RI yang ke-75 dengan harapan mewujudkan jiwa kemerdekaan bagi warga sepakat.

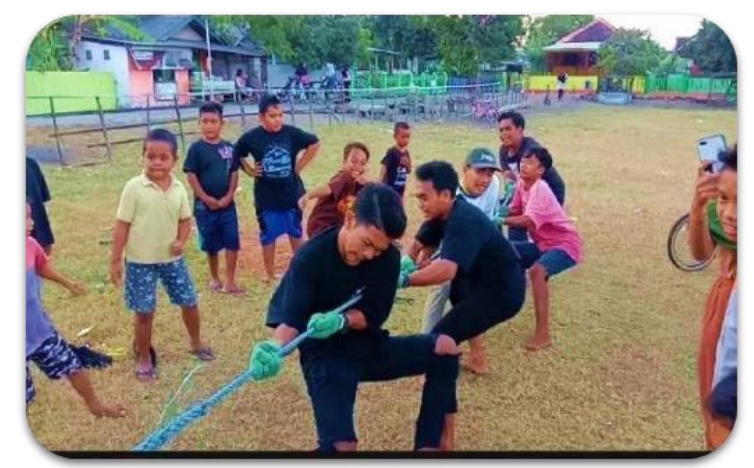

Gambar 7. Partisipasi mengikuti lomba dalam rangka HUT RI

Pembangunan gapura (pembatas desa sepakat)

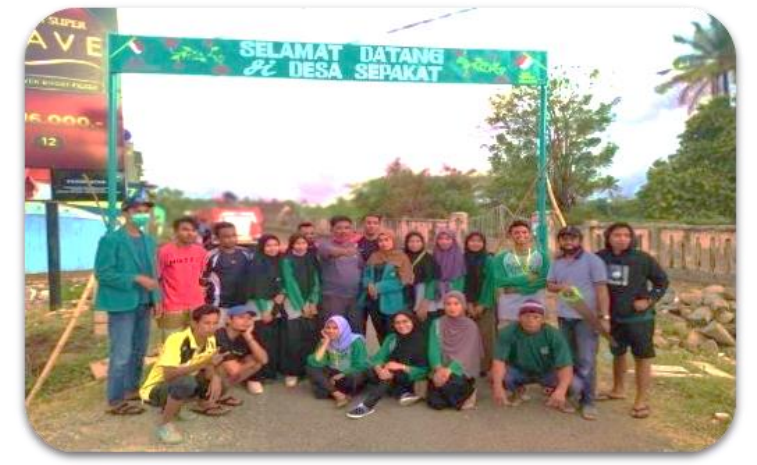

Gambar 8. Pembangunan gapura

\section{KESIMPULAN}

Kegiatan KKN di Desa Sepakat, Kecamatan Plampang yang dilaksanakan dari tanggal 03 Agustus - 03 September 2020 telah berhasil dilakukan. Kegiatan dilakukan untuk memberikan edukasi mengenai pencegahan COVID-19 dan pentingnya penggunaan protokol kesehatan guna menanggulangi COVID-19 serta upaya meningkatkan tata kelola desa di Desa Sepakat, Kecamatan Plampang. Untuk menunjang pencegahan COVID-19, telah dilaksanakan program kerja KKN Edisi COVID-19 yaitu penempelan poster edukasi COVID19 di masjid dan pasar, demonstrasi cara cuci tangan dengan baik dan benar sesuai anjuran WHO, pembagian masker dan Hand Sanitizer kepada masyarakat yang terdampak covid-19, sosialisasi BUMDes tentang ketahanan ekonomi di masa pandemi covid-19, di Desa Sepakat 
Kecamatan Plampang. Kegiatan dimaksudkan agar masyarakat paham mengenai pentingnya pengguaan protokol kesehatan saat melakukan aktivitas di luar rumah serta salah satu bentuk upaya dalam tata kelola desa pada masa pandemi COVID-19.

\section{UCAPAN TERIMA KASIH}

Terima Kasih kepada warga Desa Sepakat yang sudah berpartisipasi guna terlaksananya KKN Edisi COVID-19 yang di adakan oleh Lembaga Penelitian dan Pengabdian kepada Masyarakat (LPPM) KKN-PPM Tematik Universitas Islam Malang. Dengan dilaksanakannya program kerja tersebut diharapkan dapat membuat perubahan-perubahan sebagai upaya meningkatkan tata kelola desa di masa pandemi COVID-19 dan semoga pandemi ini segera berakhir.

\section{DAFTAR RUJUKAN}

Darmalaksana, W., Hambali, R., Masrur, A., \& Muhlas, M. (2020). Analisis Pembelajaran Online Masa WFH Pandemic Covid-19 sebagai Tantangan Pemimpin Digital Abad 21. Karya Tulis Ilmiah (KTI) Masa Work From Home (WFH) Covid-19 UIN Sunan Gunung Djati Bandung, 1-12.

Guan, W. J., Ni, Z. Y., Hu, Y., Liang, W. H., Ou, C. Q., He, J. X., ... \& Du, B.(2020). Clinical characteristics of coronavirus disease 2019 in China. New England journal of medicine, 382(18), 1708-1720.

Kemendesa. (2020) Protokol Relawan Desa Lawan COVID-19. Jakarta: Kementerian Desa, Pembangunan Daerah Tertinggal, dan Transmigrasi.

Kemendikbud. (2020) 'Perluas Akses Belajar di Masa Covid-19, Mendikbud Luncurkan Program Belajar dari Rumah’ Kementerian Pendidikan dan Kebudayaan. [online]. Tersedia di: https://www.kemdikbud.go.id/main/blog/2020/04/perluas-aksesbelajardi- masa-covid19-mendikbud-luncurkan-program-belajar-dari-rumah Diakses: 13 April 2020

MUI. (2020) Fatwa Majelis Ulama Indonesia Nomor: 14 Tahun 2020 Tentang Penyelenggaran Ibadah Dalam Situasi Terjadi Wabah Covid-19. Jakarta: Komisi Fatwa Majelis Ulama Indonesia.

Telaumbanua, D. (2020). Urgensi Pembentukan Aturan Terkait Pencegahan Covid-19 Di Indonesia. QALAMUNA: Jurnal Pendidikan, Sosial, dan Agama, 12(01), 59-70. 